\title{
EFFECTS OF DEEP-FRYING PALM OIL AND EXERCISE ON SPERM AND BIOCHEMICAL PARAMETERS IN MICE
}

\author{
VEDAT SAĞMANLIGIL*; DILEK ARSOY**; SERKAN SAYINER; AYFER FINDIK ${ }^{\ddagger}$ \\ and NURHAYAT GÜLMEZ ${ }^{\ddagger \neq}$
}

\begin{abstract}
The aim of this study was to assess the effects of deep-frying palm oil on a number of sperm and biochemical parameters with or without low- (Ex1) and high-intensity (Ex2) swimming exercises. Mice (32 BALB/c type) were equally divided into four groups (control, palm oil, palm oil $+E x 1$ and palm oil $+E x 2$ ). The increase in epididymal fat weight in case of using palm oil was normalised in both exercises. The percentage of abnormal sperm increased in the palm oil and palm oil $+E x 2$ groups ( $p<0.01$ and $p<0.001$ respectively) whilst there was not significant different from control group in palm oil + Ex1 groups. An increase in total cholesterol after palm oil was not reversed by either swimming exercises. The increased level of triglyceride in case of palm oil with heavy exercise was higher than the control ( $p>0.05)$, palm oil and palm oil $+E x 1$ groups (both $p<0.05$ ). The comparison to the control group showed that the increase in plasma molecule and malondialdehyde $(M D A)$ levels in palm oil and palm oil $+E x 2$ exercise groups were significantly higher $(p<0.05$ and $p<0.01$ respectively). In contrast, a significant increase $(p<0.01)$ in testes $M D A$ level after using palm oil was significantly reversed in both light and heavy exercise groups ( $p<0.001$ and $p<0.01$ respectively).
\end{abstract}

Keywords: exercise, palm oil, sperm quality.

Received: 31 July 2019; Accepted: 13 March 2020; Published online: 5 October 2020.

\section{INTRODUCTION}

Studies regarding obesity agree on the harmful effects on health both in humans and domesticated animals (Chan and Woo, 2010; Hruby and $\mathrm{Hu}$, 2015; Pretlow and Corbee, 2016). Some of the main detrimental effects are seen in reproduction and

\footnotetext{
* Faculty of Veterinary Medicine,

Department of Physiology, Near East University,

99138 Nicosia, Northern Cyprus.

E-mail: vsagmanligil@gmail.com

** Faculty of Veterinary Medicine,

Department of Animal Science, Near East University,

99138 Nicosia, Northern Cyprus.

₹ Faculty of Veterinary Medicine,

Department of Biochemistry, Near East University,

99138 Nicosia, Northern Cyprus.

㧊 Faculty of Veterinary Medicine,

Department of Virology, Near East University,

99138 Nicosia, Northern Cyprus.

执 Faculty of Veterinary Medicine,

Department of Histology, Near East University,

99138 Nicosia, Northern Cyprus.
}

cardiology. A common use of cooking oil is in the deep-frying process in order to produce high qualityfried products. Not only excessive food intake and less energy expenditure but also foods which are rich in fats cause many obesity related reproductive and physiological disorders (Jungheim et al., 2012).

Palm oil is obtained from the fruits of the palm, semi-solid oil at room temperature, containing high levels of saturated fat. The consumption of palm oil is generally preferred in fast food restaurants due to the reduced costs and taste benefits (Macit and Sanlier, 2014). However, some toxic substances and oxidative reactions may be formed through the heating and repeated re-heating of cooking oil (Adam et al., 2008). A number of studies on human and experimental animals have shown the effects of thermally oxidised palm oils at systemic and organ level, with changes seen in physiology, histology and biochemistry (Ferre et al., 2001; Hariri and Thibault, 2010; Abdullah et al., 2012; Leong et al., 2012; Falade et al., 2015; Perumalla Venkata and Subramanyam, 2016; Acikel Elmas et al., 2019). 
These studies show that the repeated frying of oils cause an increase in reactive oxygen species (ROS) (Perumalla Venkata and Subramanyam, 2016). Insufficient response to ROS creates a reactive molecule and malondialdehyde (MDA) which is a predictable plasma and tissue lipid peroxidation marker (Kismali et al., 2009; Sayiner et al., 2019). ROS plays an important role in the pathogenesis of reproductive diseases as well as systemic effects in men. High amounts of ROS biosynthesis can cause spoilage of sperm components. Due to oxidative stress, sperm count, morphology and motility are negatively affected (Palmer $e t$ al., 2012).

Physical exercise is an important tool in energy balance through the regulation of lipid profiles (Acikel Elmas et al., 2019). The type of exercise is also an important factor. Studies using different animal exercise experimental models showed that regular moderate exercise has a positive effect on the physiological and biochemical parameters contrary to the high intensity exercise which can have negative consequences (Aoi et al., 2011; MartínezCarrillo et al., 2015; Campos-Rodrigue et al., 2016; Alansare et al., 2018; Acikel Elmas et al., 2019).

Numerous studies have been conducted on the health effects of fried oil consumption and separate studies have demonstrated the positive health promotions of exercise in both animal and human subjects. Nevertheless, to our knowledge there are no studies which compare fried oil consumption and regular exercise using either animal or human models. In this study, we aimed to evaluate the effects of fried palm oil in combination with two different swimming exercise regimes.

\section{MATERIALS AND METHODS}

\section{Ethical Approval}

All experimental protocols were approved by Near East University Animal Experiments Ethics Committee (Approval No: 2017/11). All applicable international, national, and/or institutional guidelines for the care and use of animals were followed.

\section{Experimental Design}

The BALB/c mice were housed in plastic cages at $22+1^{\circ} \mathrm{C}$ constant temperature with $12 \mathrm{hr}$ light/dark cycles. Food and water were available ad libitum. A total of $32 \mathrm{BALB} / \mathrm{c}$ inbred male mice were used in the study. Experimental animals were equally divided into four groups of eight animals in each group with the following feeding (Table 1) and experimental processes; i) the control group $(n=8)$ fed with standard pellet food, ii) palm oil group $(n=8)$ having standard pellet food with addition of palm oil, iii) palm oil+Ex1(n=7) having standard pellet food with addition of palm oil and trained with a light/moderate-spaced type swimming three times a week for $15 \mathrm{~min}$, and iv) palm oil+Ex2 group $(n=8)$ having standard pellet food with addition of palm oil and trained with a heavy/endurance type swimming five times a week for $60 \mathrm{~min}$ (Kwak, 2006). Swimming exercise was performed in a plastic tank $(30 \mathrm{~cm} \times 35 \mathrm{~cm} \times 30 \mathrm{~cm})$ at a water temperature of $32 \pm 3^{\circ} \mathrm{C}$. Thus, in the control group, the mice were fed with normal diet $(2.5 \%$ fat) while the animals in the experimental groups were fed with high fat ratio diet in addition to the normal diet by adding re-used palm oil (used several times in frying chicken and potato in the fast food restaurant) (Table 1). Ingredients of palm oil used in this experiment were as follows; energy - $891 \mathrm{Kcal}$; fat - 99 g; single unsaturated fatty acids $-42 \mathrm{~g}$; polyunsaturated fatty acids $-11 \mathrm{~g}$; saturated fatty acids $-45 \mathrm{~g}$; trans fatty acids $<0.99 \mathrm{~g}$; cholesterol, carbohydrate, sugar and salt $-0 \mathrm{~g}$. This product was approved by the Turkish Standardisation Institute with an enterprise number (TR-27-K-001853). Following the start of the study, the feed used in experimental animals was analysed (SafyemAr-Ge Lab., Eskisehir, Turkey) and the energy contained was determined (Table 1). The mice were allowed free access to their respective diets and water ad libitum for 63 days.

\section{Weight Gain, Feed Consumption and Energy Consumption Rates}

The body weights of mice were measured daily for 63 days in order to measure the weight gain (WG) and also the difference between the last and first days were shown as a percentage in Table 2. Daily measurements of feed consumption were calculated for each group. Feed consumption rate (FCR) was also calculated (total feed consumption / WG) and given in Table 2. Energy consumption (Table 2 ) was calculated as feed intake ( $g$ ) by each animal $x$ individual feed values given in Table 1 .

\section{Collection of Blood, Semen and Tissue Samples}

Biochemical tests were performed at the Diagnostic Laboratory of Near East University's Animal Hospital. Blood samples were collected via cardiac venipuncture into $\mathrm{K}_{2}$ ethylenediaminetetraacetic acid (EDTA) and serum separator tubes. Serum and plasma samples were then separated by centrifugation at $1500 \mathrm{~g}$ for 10 $\min$ at $+4^{\circ} \mathrm{C}$. Mice were then euthanised via cervical dislocation technique. Testes and epididymis were surgically removed. One of the testes was used to measure MDA levels, an indicator of lipid peroxidation. Samples were kept at a temperature of $-80^{\circ} \mathrm{C}$ until analysis. Cauda epididymis and ductus deferens were excised and placed in Dulbecco's 
TABLE 1. EXPERIMENTAL GROUPS AND FEEDING REGIMES USED IN THE STUDY

\begin{tabular}{|c|c|c|c|c|c|c|c|c|}
\hline Groups & Feeds & $\begin{array}{c}\text { Crude } \\
\text { protein } \\
(\%)\end{array}$ & $\begin{array}{c}\text { Crude } \\
\text { fat } \\
(\%)\end{array}$ & $\begin{array}{c}\text { Crude } \\
\text { cellulose } \\
(\%)\end{array}$ & $\begin{array}{c}\text { Starch } \\
(\%)\end{array}$ & $\begin{array}{c}\text { Ash } \\
(\%)\end{array}$ & $\begin{array}{c}\text { Dry } \\
\text { matter } \\
(\%)\end{array}$ & $\begin{array}{c}\text { Energy } \\
\left(\mathrm{Kcal} \mathrm{kg}^{-1}\right)\end{array}$ \\
\hline Control & Standard pellet diet & 19.43 & 2.48 & 4.35 & 38.97 & 6.19 & 92.03 & 2789 \\
\hline Palm oil & Standard pellet diet + palm oil & 17.18 & 15.66 & 4.18 & 33.06 & 5.69 & 93.59 & 3408 \\
\hline Palm oil + Exercise 1 & Standard pellet diet + palm oil & 17.18 & 15.66 & 4.18 & 33.06 & 5.69 & 93.59 & 3408 \\
\hline Palm oil + Exercise 2 & Standard pellet diet + palm oil & 17.18 & 15.66 & 4.18 & 33.06 & 5.69 & 93.59 & 3408 \\
\hline
\end{tabular}

TABLE 2. SOME PHYSIOLOGIC AND SPERM PARAMETERS IN THE GROUPS; CONTROL, PALM OIL, PALM OIL+EX1 (swimming exercise three times in a week for $15 \mathrm{~min}$ ) AND PALM OIL+EX2 (swimming exercise five times in a week for $1 \mathrm{hr}$ )

\begin{tabular}{|c|c|c|c|c|}
\hline Parameters & Control $(n=8)$ & Palm oil $(n=8)$ & Palm oil+Ex1 $(n=7)$ & Palm oil+Ex2 $(n=8)$ \\
\hline Weight gain (63 days, g) & $4.25 \pm 2.49$ & $4.50 \pm 2.07$ & $4.00 \pm 2.61$ & $3.75 \pm 2.59$ \\
\hline Weight gain $(\%)$ & 16.19 & 16.07 & 14.41 & 14.02 \\
\hline Feed consumption (63 days, g) & $271.3 \pm 8.01$ & $227.3 \pm 7.72^{\mathrm{a}^{*}}$ & $229.5 \pm 7.15^{\mathrm{a}^{*}}$ & $186.8 \pm 5.57^{a, b^{*}}$ \\
\hline Feed consumption rate (FCR, \%) & 63.82 & 50.50 & 57.38 & 37.35 \\
\hline Energy consumption (Kcal, 63 days) & 757 & 775 & 782 & 637 \\
\hline Epididymal fat (g) & $0.37 \pm 0.05$ & $0.52 \pm 0.08^{\mathrm{a}^{* *}}$ & $0.29 \pm 0.08^{\mathrm{b}^{* * *}}$ & $0.37 \pm 0.14^{\mathrm{b}^{*}}$ \\
\hline Sperm count $\left(\times 10^{6}\right.$ count $\left.\mathrm{ml}^{-1}\right)$ & $18.99 \pm 6.37$ & $13.13 \pm 5.14$ & $27.50 \pm 21.48$ & $37.50 \pm 19.50^{\mathrm{b}^{*}}$ \\
\hline Sperm motility $(\%)$ & $59.00 \pm 9.89$ & $62.25 \pm 14.55$ & $45.29 \pm 23.43$ & $60.00 \pm 16.80$ \\
\hline Sperm morphology (abnormal \%) & $27.88 \pm 4.49$ & $43.00 \pm 12.90^{\mathrm{a}^{* *}}$ & $30.43 \pm 15.78$ & $42.88 \pm 4.16^{\mathrm{a}^{* * *}}$ \\
\hline Seminiferous tubules scale (JS score) & $8.30 \pm 0.55$ & $7.91 \pm 0.43^{\mathrm{a}^{*}}$ & $8.77 \pm 0.28^{\mathrm{a}^{*}, \mathrm{~b}^{* * *}}$ & $8.58 \pm 0.38^{\mathrm{b}^{\star *}}$ \\
\hline
\end{tabular}

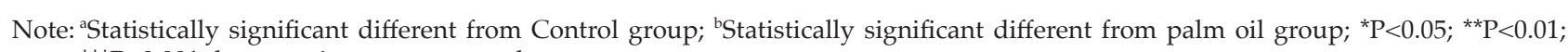
$* * * \mathrm{P}<0.001$ data are given as mean $\pm \mathrm{sd}$.

PBS medium $\left(5 \mathrm{ml},+37^{\circ} \mathrm{C}\right)$. The excised tissues were cut into small pieces inside in the medium, followed by a coating with mineral oil (FertiCult ${ }^{\circledR}$ ) and incubated for 20 min to allow the spermatozoa to diffuse into the medium. Thereafter, a microscope slide was prepared for evaluation of the motility of the spermatozoa (Absalan et al., 2008). Epidydimal fat $(\mathrm{g})$ was removed from each animal and weighed using a balance [ATX-224 ( $\mathrm{d}=0,0001 \mathrm{~g})$, Shimadzu, Kyoto, Japan].

\section{Assessment of Sperm Parameters}

Sperm motility $(\%)$, concentration $\left(\times 10^{6}\right.$ count $/$ $\mathrm{ml}$ ) and morphology (\% abnormal) were assessed according to the previously described methods (Christensen et al., 2005; Komori et al., 2006). To evaluate morphology, the fixed and dried smears were embedded with Giemsa stain for $5 \mathrm{~min}$. All parameters were evaluated under light microscope (DM500, Leica Microsystems, Wetzlar, Germany).

\section{Measurement of Blood Total Cholesterol, Triglyceride, Lactate and Testosterone Concentrations}

Total cholesterol (in $\mathrm{mg} \mathrm{dl}^{-1}$ ), triglycerides (in $\mathrm{mg}$ $\mathrm{dl}^{-1}$ ) and lactate concentrations were measured in serum samples using automated chemistry analyser (BS120, Mindray, Shenzhen, China). Competitive enzyme-linked immunosorbent assay (ELISA) test (Testosterone, DE1559, Lot. 29K126, Demeditec, Kiel, Germany) was performed for the measurement of serum testosterone concentration (in $\mathrm{ng} \mathrm{ml}^{-1}$ ). The ELISA test was performed according to the manufacturer's directions using an automated microtiter washer (MW-12A Microplate washer, Mindray, Shenzhen, China) and a microtiter plate reader at $450 \mathrm{~nm}$ (MR-96A Microplate reader, Mindray, Shenzhen, China).

\section{Measurement of Blood and Testes Tissue MDA Levels}

The degree of lipid peroxidation was measured by performing an MDA assay. A commercially available assay kit (TBARS Assay Kit, Item No. 10009055, Batch No. 0502129, Cayman Chemicals, Michigan, USA) was used as per manufacturer's directions. Plasma samples were directly treated. RIPA buffer (Item No. 10010263, Batch No. 0490889-1, Cayman Chemicals, Michigan, US) and Dounce tissue grinder set (D8938, Lot. 3110, Sigma-Aldrich, Missouri, US) on ice were used to homogenise testes tissues. Following homogenisation, samples were centrifuged at $1600 \mathrm{~g}$ for $10 \mathrm{~min}$ at $+4^{\circ} \mathrm{C}$ and supernatants were used for analysis. The principle measurement is based on the reaction with thiobarbituric acid (TBA) in boiling water for 60 min using acidic medium and measurement of 
the absorbance of the reaction mixture at $532 \mathrm{~nm}$ (Ohkawa, et al., 1979). Absorbance was measured with a UV/VIS Spectrophotometer (Model T70, S/N:17-1814-01-0059, PG Instruments Ltd, UK). Plasma and tissue MDA concentrations were expressed as $\mu \mathrm{mol}$ litre $^{-1}$ and $\mu \mathrm{mol}$ MDA g-1, respectively.

\section{Histological Examination of Testes}

Testicle tissue samples were fixed in $10 \%$ neutral formalin and embedded in paraffin using standard procedures. The $5 \mu \mathrm{m}$ sections of the paraffin tissue blocks were stained with Haematoxylin and Eosin and then examined using a Leica DM500 light microscope coupled with a Leica Microsystem Framework integrated digital imaging analysis system (Leica Application Suit version 3.0 Serial 38132019 Leica ICC50 HD, Heerbrugg, Switzerland). Seminiferous tubules were scaled (50 tubules per animals) according to Johnsen's Tubular Biopsy Scores (JS) (Johnsen, 1970).

\section{Statistical Analyses}

Statistical analyses were performed using the GraphPad Prism 7.0 software (GraphPad Software Inc., San Diego; CA; ABD). Groups were compared using analysis of variance (ANOVA) with a post hoc Tukey's multi-comparison test. The $p<0.05$ was accepted as statistically significant.

\section{RESULTS}

During the experimental work the light exercise group (palm oil+Ex1) had one fatality reducing the group size to seven individuals.

In the study, animal weight gains did not significantly change in cases provided with palm oil and applying a moderate and heavy exercise programme. Although these calculations are given both in grams and percentage values, levels for exercise groups were both smaller than the control and palm oil given groups (Table 2). Assessing the feed consumption both in the amount used and the percentage of this usage showed that the groups which received palm oil without exercise and with short-term exercise consumed similar amounts of feed and those were significantly less than that in the control group $(p<0.05)$. However, significantly the lowest amount of feed taken was by the group receiving palm oil and heavy exercise and this value was significantly different $(p<0.05)$ from the palm oil and palm oil+Ex1 groups (Table 2).

Epididymal fat amount increased significantly in the palm oil group compared to the control group $(p<0.01)$. However, in the palm oil+Ex1 and palm oil+Ex2 groups, the improved values were significantly smaller than that of palm group $(\mathrm{p}<0.001$ and 0.05 respectively; Table 2). These values were not significantly different to the control group.

The sperm counts in palm oil+Ex2 group were higher than that of the other groups and the difference was statistically significant $(p<0.05)$. No statistically significant difference among the other three groups (Table 2).

In terms of sperm motility, no significant differences were found between the groups, and the results demonstrate that there is no significant effect of palm oil consumption on the parameter in the BALB/c mouse model (Table 2).

Morphologic examination for percentage of abnormal sperms (Figure 1) showed that the results in palm oil and palm oil+Ex2 groups were significantly higher than control and palm oil+Ex1 groups $(\mathrm{p}<0.01$ and 0.001 , respectively $)$. No difference existed between the control and palm oil+Ex1 groups (Table 2).

Seminiferous tubules of the testicles were evaluated as Johnson score values (Table 2). Histological examinations of the testes showed a significant decrease in seminiferous tubule scale in the palm oil group when compared to the control group $(p<0.05)$. Also, the tubule scores of palm oil+Ex1 and palm oil+Ex2 groups were significantly higher than that of palm oil group $(p<0.001$ and 0.01 , respectively). The results of palm oil+Ex1 group was also significantly higher $(p<0.001)$ than that of control group (Table 2). The visual differences are also demonstrated in Figure 2.

Total cholesterol levels in blood (showing lipid profile systematically) were significantly increased in all experimental groups compared to the control group $(p<0.05-0.01)$. Triglyceride level of the palm oil+Ex2 group was significantly higher than both the palm oil and the palm oil+Ex1 groups $(p<0.05)$. Lactate and testosterone levels were not significantly different between the groups (Table 3 ).

MDA levels measured as an important degradation product of lipid peroxidation in plasma and testicular tissues increased in the palm oil group compared to the control group $(\mathrm{p}<0.05$ and $\mathrm{p}<0.01$, respectively). In the palm oil+Ex2 group, plasma MDA levels increased compared to the control group $(\mathrm{p}<0.01)$. In the palm oil+Ex1 group subjected to mild swimming exercise, it was found that the plasma MDA level decreased to the same levels as the control group. As a result of the statistical evaluation of the testis tissues, it was found that MDA values of both light swimming (palm oil+Ex1) and heavy swimming (palm oil+Ex2) groups decreased significantly compared to the palm oil group $(p<0.001$ and $p<0.01$, respectively). Additionally, the findings of both exercise groups did not differ with the control group ( $\mathrm{p}>0.05 ;$ Table 3$)$. 
TABLE 3. SOME BIOCHEMICAL PARAMETERS IN THE GROUPS; CONTROL, PALM OIL, PALM OIL+EX1 (swimming exercise three times in a week for $15 \mathrm{~min}$ ) AND PALM OIL+EX2 (swimming exercise five times in a week for $1 \mathrm{hr}$ )

\begin{tabular}{|c|c|c|c|c|}
\hline Parameters & Control $(n=8)$ & Palm oil $(n=8)$ & Palm oil+Ex1 $(n=7)$ & Palm oil + Ex2 $(n=8)$ \\
\hline Cholesterol, total $\left(\mathrm{mg} \mathrm{dl}^{-1}\right)$ & $96.07 \pm 21.11$ & $132.70 \pm 18.25^{\mathrm{a}^{*}}$ & $138.70 \pm 32.99^{a^{* *}}$ & $134.40 \pm 13.34^{\mathrm{a}^{* *}}$ \\
\hline Triglycerides $\left(\mathrm{mg} \mathrm{dl}^{-1}\right)$ & $80.03 \pm 23.29$ & $53.40 \pm 15.46$ & $59.68 \pm 21.17$ & $94.30 \pm 33.51^{\text {b. } c^{*}}$ \\
\hline Lactate (mmol litre $\left.{ }^{-1}\right)$ & $6.98 \pm 2.72$ & $6.36 \pm 2.71$ & $5.78 \pm 1.42$ & $4.55 \pm 1.29$ \\
\hline Testosterone (ng ml-1) & $2.23 \pm 2.46$ & $2.66 \pm 2.31$ & $3.18 \pm 3.19$ & $2.88 \pm 2.94$ \\
\hline Plasma MDA ( $\mu$ mol litre $\left.{ }^{-1}\right)$ & $15.28 \pm 2.38$ & $21.60 \pm 4.33^{a^{*}}$ & $17.28 \pm 3.96$ & $23.13 \pm 6.13^{\mathrm{a}^{* *}}$ \\
\hline Testes MDA ( $\mu \mathrm{mol} \mathrm{g}^{-1}$ tissue) & $10.32 \pm 4.17$ & $16.64 \pm 2.60^{\mathrm{a}^{* *}}$ & $7.97 \pm 2.63^{b^{* * * *}}$ & $9.70 \pm 3.56^{b^{* *}}$ \\
\hline
\end{tabular}

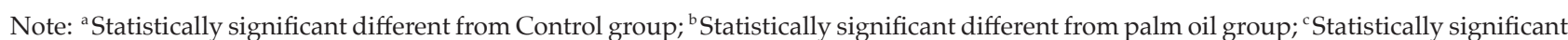
different from palm oil+Ex1 group; ${ }^{*} \mathrm{P}<0.05 ;{ }^{* *} \mathrm{P}<0.01 ;{ }^{* *} \mathrm{P}<0.00$. Data are given as mean \pm standard deviation.

\section{DISCUSSION}

Palm oil, which is preferred in the food industry because of its low cost compared to other oils, is said to be related to the risk of disease development due to dyslipidemia and infertility caused by its high saturated fatty acid content (Sundram et al., 2003; Fan et al., 2017).

Male fertility problems are also associated with increased total cholesterol and triglyceride levels. Mouse experiments using deep fried palm oil have been reported to cause an increase in triglyceride and total cholesterol levels in blood serum (ViguerasVillaseñor et al., 2011). In our study, there was no change in cholesterol levels when compared to the palm group in swimming exercises. In contrast, the triglyceride level of the heavy exercised group increased compared to the palm oil and palm oil+Ex1 group whilst it did not differ with the control group. The results of triglyceride level are thought to be related to the mouse gender used in the experimental model. It is thought that the BALB/c type mice do not accumulate excess triglycerides in the liver with high fat diet, which may be associated with low fatty acid involvement (Montgomery et al., 2013). Additionally, in the palm oil+Ex2 group, an increased level of triglycerides was similar to the control group and it is thought to be due to the intensive exercise activity (60 min). Skeletal muscle cells contain significant amounts of triglycerides. These intramyocellular triglycerides are used as a major source of energy during long-term exercise. Endurance training is reported to trigger the use of more intramuscularly stored triglycerides, which does not increase the overall body lipolytic response during exercise (Horowitz and Klein, 2000; Johnson et al., 2004). In addition, Falade et al. (2015) found that blood triglyceride levels were lower in rats fed thermally oxidised palm oil compared to the groups fed with a normal diet. This result is in line with the findings obtained in our study.

Lactate level increases with anaerobic glycolysis during or after intense exercise. In a study of mice using different swimming intensities, no significant difference was found between the levels of plasma lactate during the resting state after exercise (Huang et al., 2016). In our study, no difference was found in the palm oil+Ex1 and palm oil+Ex2 groups fed with the high-fat diet along with the other groups. An insignificant increase in serum testosterone levels after using palm oil (Table 3) was consistent with the results of the sperm count (Table 2).

Oluba et al. (2012) found serum lipid peroxidation rates of rats fed with palm oil was significantly less than the control group. In contrast, there are also studies showing that palm oil has negative effects on cardiovascular and urogenital diseases due to high level of heat treatment (Adam et al., 2008; Chen et al., 2011; Xian et al., 2012). The levels of total cholesterol and thiobarbituric acid-reactive substances (TBARS) were significantly higher in rats fed with heated palm oil compared to the control group. The results of our study also showed the negative effects of fried palm oil on serum lipid profile in parallel with previous published findings (Adam et al., 2008; Rezq et al., 2010; Fattore et al., 2014). MDA levels, lipid-peroxydathione end products in the palm oil treated group, were significantly increased in both the serum and testis tissue (Table 3).

In many pathologic cases where oxidantantioxidant balance is impaired, exercise is known to prevent lipid peroxidation and thus decrease MDA levels (Acikel Elmas et al., 2019). In our study, a significant improvement was observed in MDA levels in both the plasma and testis tissues in the group treated with palm oil and moderate swimming (palm oil+Ex1). Comparisons showed that there was a significant improvement in the palm oil group and a decrease in the control group. On the other hand, plasma and testis MDA levels were higher in the palm oil+Ex2 group than in the palm oil+Ex1 group. In a study by Barreto et al. (2012), MDA levels were found to increase in the tissues as a result of endurance type exercise.

In our study, no significant weight gain was seen in animals although they received a high calorific diet with palm oil and harboured more epididymal adipose tissue. Moreover, the difference between the feed consumption among the animals was not reflected in their body weight. This may be due 
to the mouse gender selected for the experiment. The BALB/c is resistant to produce increased body weight in case of having high fat diet (Montgomery et al., 2013). This was preferred in choosing animal model to eliminate the adverse effects of weight gain.

Palm oil diet did not have adverse effects in many parameters except sperm morphology. Decrease in sperm count at the rate of a third was also observable but not significantly different due to high standard deviation.

The main white adipose tissue pads are the inguinal and epididymal, with the latter being the most frequent dissected pad (Chusyd et al., 2016). In rodents, the inguinal fat pad is comparable in terms of location to the large gluteofemoral subcutaneous depot in humans (Chusyd etal., 2016). Gluteofemoral fat in humans has been shown to have a protective role, such that is independently associated with lower triglyceride levels (Snijder et al., 2005). The increase in the epididymal (gonadal) fat due to palm oil consumption is quite understandable due to its high calorific value. Short- and long-term exercises decreased the fat levels. Some previous studies have demonstrated that high fat diet led to a decrease in the testosterone levels and increase in fat mass of the epididymis (Vigueras-Villaseñoret al., 2011; Erdemir et al., 2012), sperm quality without a decrease in motility (Fernandez et al.,
2011). In our study, the results showed similarity with those results. The results demonstrate that hard exercise and palm oil can increase abnormal sperm rates. Nevertheless, it is appeared that a balanced exercise can restore the adverse effects of palm oil consumption on sperm abnormalities.

There are many studies conducted on negative health effects of excess consumption of palm oil or heat-treated palm oil. The serum lipid peroxidation, cholesterol, TBRAS, ROS, cardiovascular and urogenital systems have been stated to be affected adversely (Adam et al., 2008; Rezq et al., 2010; Chen et al., 2011; Xian et al., 2012; Oluba et al., 2012; Fattore et al., 2014). In a previous study, we found the same effect using sunflower oil (Sayiner et al., 2019). In this study, we did not come across to a result that demonstrates the negative health effect of consumption of palm oil with diet on the sperm counts and sperm motility (Table 2). Nevertheless, we found some differences in the sperm morphology (Figure 1) and tubule scores (Table 2) of palm group when compared with the control group. Also, exercise (palm oil+Ex1 and palm oil+Ex2) appeared to be mostly effective on the tubule scores (Table 2, Figure 2). The results are most probably due to excess heat treatment, not due to the type of oil. Further research should be conducted on these topics before definitive conclusions can be drawn.
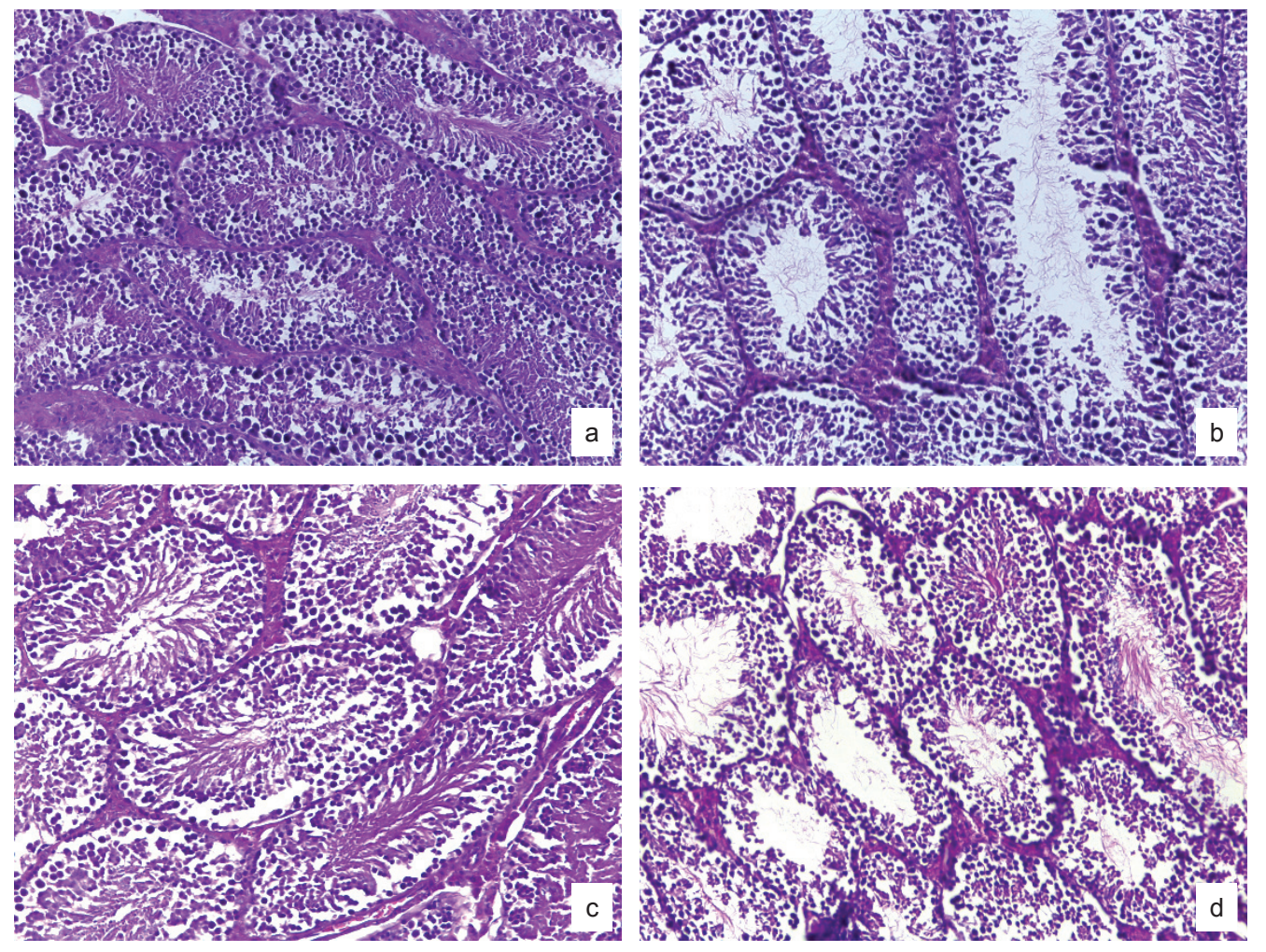

Figure 1. Seminiferous tubules epithelium. (a) Seminiferous tubule scale (8.30) of Control group, (b) seminiferous tubule scale (7.91) of palm oil group, (c) seminiferous tubule scale (8.77) of palm oil + Ex1 and (d) seminiferous tubule scale (8.58) of palm oil +Ex2 group [haemotoxylin and eosin (HEE), 200X]. 

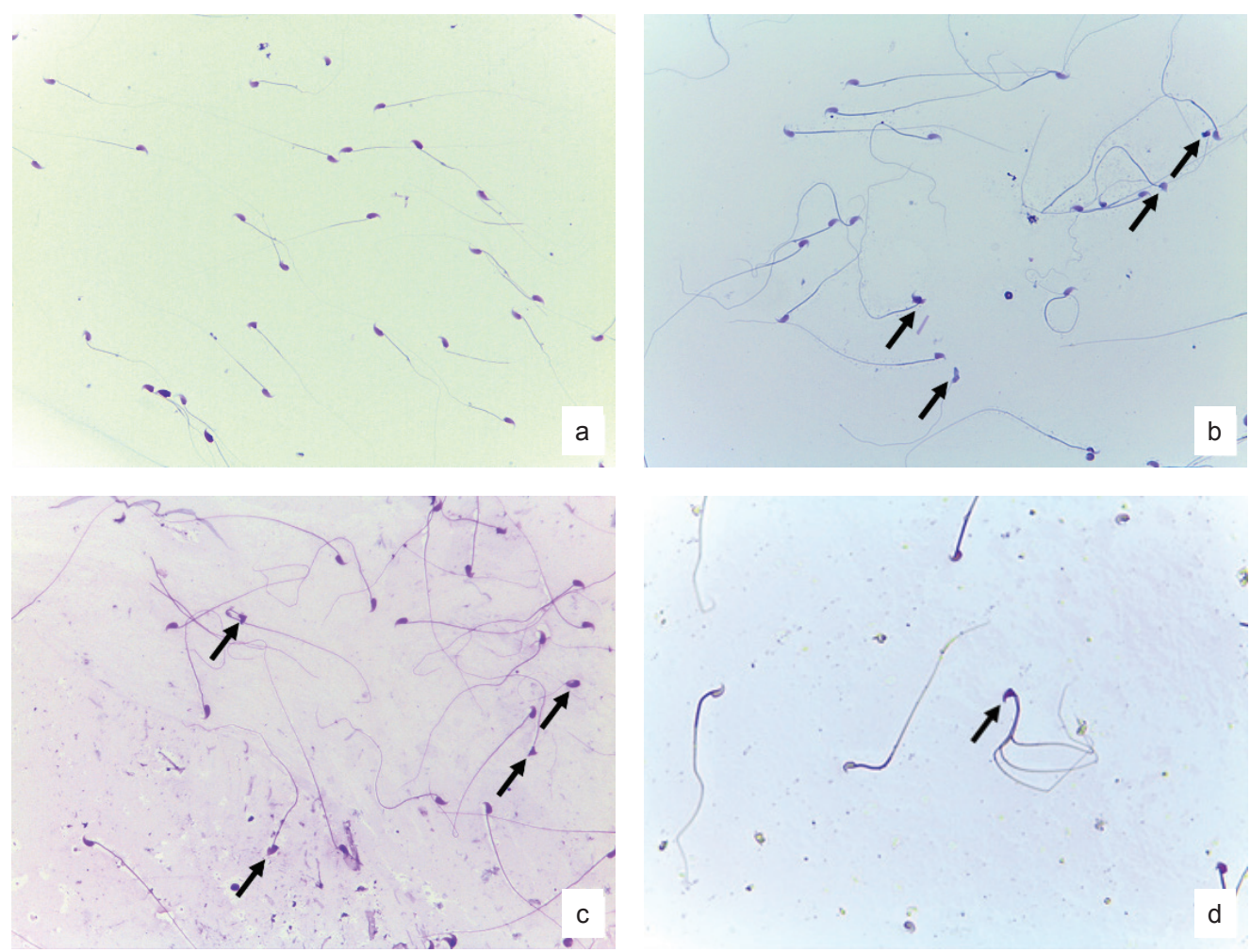

Figure 2. Sperm smear stained with Giemsa. (a) Control group 400X, (b) palm oil group 400X, (c) palm oil +Ex1 group 400X and (d) palm oil+Ex2 group 400X. Arrows indicate abnormal sperm.

\section{CONCLUSION}

High fat diet and high intensity exercise can lead to negative effect on blood and tissue parameters. Fried palm oil can cause harmful effects on blood and sperm parameters which are indicators of healthy individuals. Our findings suggest that consumption of fried palm oil can be mitigated by mild-intermittent swimming exercise. However, these results are not seen in the heavy/endurance exercise group where levels of some parameters are similar to/or are higher than the control group. Therefore, the level of exercise should be carefully considered when evaluating the effect of palm oil on physiological processes. However, we could not fully study the action mechanisms of the negative effects of fried oils and high intensity exercises. These parameters should be fully examined with a much larger study.

\section{ACKNOWLEDGEMENT}

This research was made possible from the research project 2017-01-029 of the Scientific Research Unit, Center of Excellence of Near East University. We are also thankful to Assistant Prof Dr Özgür Tosun for excellent assistance in statistical analyses.

\section{REFERENCES}

Abdullah, A; Mohd Shahrul, S; Chan, S X; Noorhazliza, A; Khairunnisak, M; Nur Azlina, M F; Qodriyah, H M S; Kamisah, Y and Jaarin, K (2012). Level of knowledge, attitude and practice of night market food outlet operators in Kuala Lumpur regarding the usage of repeatedly heated cooking oil. Med. J. Malaysia, 67(1): 91-101.

Absalan, F; Movahedin, M and Mowla, S J (2008). Assesment of testis histological changes and sperm parameters in experimentally-induced unilateral and bilateral cryptorchid mouse model. Iran. J. Reprod. Med., 67(3): 143-148.

Acikel Elmas, M; Cakici, S E; Dur, I R; Kozluca, I; Arinc, M; Binbuga, B; Bingol Ozakpınar, O; Kolgazi, M; Sener, G and Ercan, F (2019). Protective effects of exercise on heart and aorta in high-fat diet-induced obese rats. Tissue Cell, 57: 57-65.

Adam, S K; Soelaiman, I N; Umar, N A; Mokhtar, $\mathrm{N}$; Mohamed, N and Jaarin, K (2008). Effects of repeatedly heated palm oil on serum lipid profile, lipid peroxidation and homocysteine levels in a post-menopausal rat model. Mcgill J. Med., 11(2): $145-151$. 
Alansare, A; Alford, K; Lee, S; Church, T and Jung, H C (2018). The effects of high-intensity interval training vs. moderate-intensity continuous training on heart rate variability in physically inactive adults. Int. J. Environ. Res. Public Health, 15(7): 1508.

Aoi, W; Naito, Y; Hang, L P; Uchiyama, K; Akagiri, S; Mizushima, K and Yoshikawa, T (2011). Regular exercise prevents high-sucrose diet-induced fatty liver via improvement of hepatic lipid metabolism. Biochem. Biophys. Res. Commun., 413(2): 330-335.

Barreto, T O; Cleto, LS; Gioda, C R; Silva, R S; CampiAzevedo, A C; De Sousa-Franco, J; de Magalhaes, J C; Penaforte, C L; Pinto, K M; Cruz Jdos, J D and RochaVieira, E (2012). Swim training does not protect mice from skeletal muscle oxidative damage following a maximum exercise test. Eur. J. Appl. Physiol., 112(7): 2523-2530.

Campos-Rodrigue, R; Godinez-Victoria, $\mathrm{M}$; Arciniega-Martinez, I M; Resendiz-Albor, A A; Reyna-Garfias, H; Cruz-Hernandez, $\mathrm{T} R$ and Drago-Serrano, M E (2016). Protective effect of moderate exercise for BALB/c mice with Salmonella typhimurium infection. Int. J. Sports Med.: 63-70.

Chan, R S M and Woo, J (2010). Prevention of overweight and obesity: How effective is the current public health approach. Int. J. Environ. Res. Public Health, 7(3): 765-783.

Chen, B K; Seligman, B; Farquhar, J W and GoldhaberFiebert, J D (2011). Multi-country analysis of palm oil consumption and cardiovascular disease mortality for countries at different stages of economic development 1980-1997. Global. Health, 7: 45.

Christensen, P; Stryhn, H and Hansen, C (2005). Discrepancies in the determination of sperm concentration using Bürker-Türk, Thoma and Makler counting chambers. Theriogenology, 63: 9921003.

Chusyd, D E; Wang, D; Huffman, D M and Nagy, T R (2016). Relationships between rodent white adipose fat pads and human white adipose fat depots. Front. Nutr., 3: 10.

Erdemir, F; Atilgan, D; Markoc, F; Boztepe, O; Suha-Parlaktas, B and Sahin, S (2012). Efecto de la obesidad inducida por dieta en el tejido testicular y parámetros de estrés oxidativo en el suero. Actas Urol Esp., 36(3): 153-159.

Falade, AO; Oboh, G; Ademiluyi, AO and Odubanjo, O V (2015). Consumption of thermally oxidized palm oil diets alters biochemical indices in rats. BeniSuef Univ. J. Basic Appl. Sci., 4(2): 150-156.
Fan, W; Xu, Y; Liu, Y; Zhang, Z; Lu, L and Ding, Z (2017). Obesity or overweight, a chronic inflammatory status in male reproductive system, leads to mice and human subfertility. Front. Physiol., 8: 1117.

Fattore, E; Bosetti, C; Brighenti, F; Agostoni, C and Fattore, G (2014). Palm oil and blood lipid-related markers of cardiovascular disease: A systematic review and meta-analysis of dietary intervention trials. Am. J. Clin. Nutr., 99(6): 1331-1350.

Fernandez, C D B; Bellentani, F F; Fernandes, G S A; Perobelli, J E; Favareto, A P A; Nascimento, A F; Cicogna, A C and Kempinas, W D G (2011). Dietinduced obesity in rats leads to a decrease in sperm motility. Reprod. Biol. Endocrinol., 9: 32.

Ferre, N; Camps, J; Paul, A; Cabre, M; Calleja, L; Osada, J and Joven, J (2001). Effects of high-fat, lowcholesterol diets on hepatic lipid peroxidation and antioxidants in apolipoprotein E-deficient mice. Mol. Cell. Biochem., 218: 165-169.

Hariri, N and Thibault, L (2010). High-fat dietinduced obesity in animal models. Nutr. Res. Rev., 23(2): 270-299.

Horowitz, J F and Klein, S (2000). Lipid metabolism during endurance exercise. Am. J. Clin. Nutr., 72: 558S-563S.

Hruby, A and Hu, F B (2015). The epidemiology of obesity: A big picture. Pharmacoeconomics, 33(7): 673689.

Huang, W C; Hsu, Y J; Wei, L; Chen, Y U and Huang, C C (2016). Association of physical performance and biochemical profile of mice with intrinsic endurance swimming. Int. J. Med. Sci., 13(12): 892-901.

Johnsen, S G (1970). Testicular biopsy score count - A method for registration of spermatogenesis in human testes: Normal values and results in 335 hypogonadal males. Horm. Res. Paediatr., 1: 2-25.

Johnson, N A; Stannard, S R and Thompson, M W (2004). Muscle triglyceride and glycogen in endurance exercise: Implications for performance. Sports Med., 34: 151-164.

Jungheim, E S; Travieso, J L; Carson, K R and Moley, K H (2012). Obesity and reproductive function. Obstet. Gynecol. Clin. North Am., 39(4): 479-493.

Kismali, G; Ozgur, E; Sayiner, S; Alpaslan, B; Guler, G; Seyhan, N and Sel, T (2009). The effects of epigallocatechin gallate and $\mathrm{N}$-acetylcysteine on mobile phone-induced oxidative stress in Guinea pigs. J. Anim. Vet. Adv., 8(5): 959-961. 
Komori, K; Tsujimura, A; Ishijima, S; Tanjapatkul, P; Fujita, K; Matsuoka, Y; Takao, T; Miyagawa, Y; Takada, S and Okuyama, A (2006). Comparative study of sperm motility analysis system and conventional microscopic semen analysis. Reprod. Med. Biol., 5(3): 195-200.

Kwak, Y-S (2006). Effects of training on spleen and peritoneal exudate reactive oxygen species and lymphocyte proliferation by splenocytes at rest and after an acute bout of exercise. J. Sports Sci., 24(9): 973-978.

Leong, X-F; Salimon, J; Mustafa, M R and Jaarin, K (2012). Effect of repeatedly heated palm olein on blood pressure-regulating enzymes activity and lipid peroxidation in rats. Malays. J. Med. Sci., 19(1): 20-29.

Macit, S and Sanlier, N (2014). Palm yağı ve sağlık (palm oil and health). J. Tour. Gastron. Stud., 2: 1320.

Martínez-Carrillo, B E; Jarillo-Luna, R A; CamposRodríguez, R; Valdés-Ramos, $\mathrm{R}$ and RiveraAguilar, V (2015). Effect of diet and exercise on the peripheral immune system in young Balb/c mice. Biomed. Res. Int., 2015.

Montgomery, M K; Hallahan, N L; Brown, S H; Liu, M; Mitchell, T W; Cooney, G J and Turner, N (2013). Mouse strain-dependent variation in obesity and glucose homeostasis in response to high-fat feeding. Diabetologia, 56: 1129-1139.

Ohkawa, H; Ohishi, N and Yagi, K (1979). Assay for lipid peroxides in animal tissues by thiobarbituric acid reaction. Anal. Biochem., 95(2): 351-358.

Oluba, O; Onyeneke, C; Ojieh, G; Eidangbe, G and Orole, R (2012). Effects of palm oil supplementation on lipid peroxidation and glutathione peroxidase activity in cholesterol-fed rats. Internet J. Cardiovasc. Res., 6: 1-6.

Palmer, N O; Bakos, H W; Fullston, $\mathrm{T}$ and Lane, M (2012). Impact of obesity on male fertility, sperm function and molecular composition. Spermatogenesis, 2(4): 253-263.

Perumalla Venkata, R and Subramanyam, R (2016). Evaluation of the deleterious health effects of consumption of repeatedly heated vegetable oil. Toxicol. Reports, 3: 636-643.

Pretlow, R A and Corbee, R J (2016). Similarities between obesity in pets and children: The addiction model. Br. J. Nutr., 116(5): 944-949.

Rezq, A A; Labib, F A and Attia, A E M (2010). Effect of some dietary oils and fats on serum lipid profile, calcium absorption and bone mineralization in mice. Pakistan J. Nutr., 9(7): 643-650.

Sayiner, S; Gulmez, N; Sabit, Z and Gulmez, M (2019). Effects of deep-frying sunflower oil on sperm parameters in a mouse model: Do probiotics have a protective effect? Kafkas Univ. Vet. Fak. Derg. p. 1-7.

Snijder, M B; Visser, M; Dekker, J M; Goodpaster, B H; Harris, T B; Kritchevsky, S B; De Rekeneire, N; Kanaya, A M; Newman, A B; Tylavsky, F A and Seidell, J C (2005). Low subcutaneous thigh fat is a risk factor for unfavourable glucose and lipid levels, independently of high abdominal fat. The health ABC study. Diabetologia, 48: 301-308.

Sundram, K; Sambanthamurthi, R and Tan, Y A (2003). Palm fruit chemistry and nutrition. Asia Pac. J. Clin. Nutr., 12: 355-362.

Vigueras-Villaseñor, R M; Rojas-Castañeda, J C; Chávez-Saldaña, M; Gutiérrez-Pérez, O; GarcíaCruz, M E; Cuevas-Alpuche, O; Reyes-Romero, M M and Zambrano, E (2011). Alterations in the spermatic function generated by obesity in rats. Acta Histochem., 113(2): 214-220.

Xian, T K; Omar, N A; Ying, L W; Hamzah, A; Raj, S; Jaarin, K; Othman, F and Hussan, F (2012). Reheated palm oil consumption and risk of atherosclerosis: Evidence at ultrastructural level. Evidence-based Complement. Altern. Med., 2012: 1-6. 